\title{
A review of modern treeline migration, the factors controlling it and the implications for carbon storage
}

\author{
HANSSON Amanda ${ }^{*}$ (D) https://orcid.org/oooo-ooo1-5290-1247; e-mail: a.hansson@uq.edu.au \\ DARGUSCH Paul ${ }^{1}$ (D) https://orcid.org/oooo-ooo1-9255-2803; e-mail: p.dargusch@uq.edu.au
}

SHULMEISTER Jamie ${ }^{1,2}$ (D) https://orcid.org/oooo-ooo1-5863-9462; e-mail: james.shulmeister@canterbury.ac.nz

\author{
${ }^{*}$ Corresponding author \\ 1 School of Earth and Environmental Science, University of Queensland, Brisbane QLD 4072, Australia \\ 2 School of Earth and Environment, University of Canterbury, Christchurch 8140, New Zealand
}

Citation: Hansson A, Dargusch P, Shulmeister J (2021) A review of modern treeline migration, the factors controlling it and the implications for carbon storage. Journal of Mountain Science 18(2). https://doi.org/10.1007/s11629-020-6221-1

(C) The Author(s) 2021.

\begin{abstract}
Numerous studies have reported that treelines are moving to higher elevations and higher latitudes. Most treelines are temperature limited and warmer climate expands the area in which trees are capable of growing. Hence, climate change has been assumed to be the main driver behind this treeline movement. The latest review of treeline studies was published in 2009 by Harsch et al. Since then, a plethora of papers have been published studying local treeline migration. Here we bring together this knowledge through a review of 142 treeline related publications, including 477 study locations. We summarize the information known about factors limiting tree-growth at and near treelines. Treeline migration is not only dependent on favorable growing conditions but also requires seedling establishment and survival above the current treeline. These conditions appear to have become favorable at many locations, particularly so in recent years. The review revealed that at $66 \%$ of these treeline sites forest cover had increased in elevational or latitudinal extent. The physical form of treelines influences how likely they are to migrate and can be used as an indicator when predicting future treeline movements. Our analysis also revealed that while a greater percentage of
\end{abstract}

Received: 22-May-2020

1st Revision: 21-Sep-2020 $^{\text {st }}$

$2^{\text {nd }}$ Revision: $13-$ Nov-2020

Accepted: 14-Dec-2020 elevational treelines are moving, the latitudinal treelines are capable of moving at greater horizontal speed. This can potentially have substantial impacts on ecosystem carbon storage. To conclude the review, we present the three main hypotheses as to whether ecosystem carbon budgets will be reduced, increased or remain the same due to treeline migration. While the answer still remains under debate, we believe that all three hypotheses are likely to apply depending on the encroached ecosystem. Concerningly, evidence is emerging on how treeline migration may turn tundra landscapes from net sinks to net sources of carbon dioxide in the future.

Keywords: Treeline advance; Treeline migration; Forest dynamics; Alpine forests; Ecosystem carbon storage; Carbon sequestration; Global meta-analysis.

\section{Introduction}

Climate change has caused a rapid change to the distribution, composition, and function of many species and ecosystems on a global scale (Pecl et al. 2017). With climatic boundaries shifting, species will often have to migrate to track their suitable environment. The ability of a species to do so largely determines what novel species combinations we are 
likely to see in the future. Tracking species migration is important as competition from novel species can make the survival of endemic species difficult and can force continued upwards migration (Warszawski et al. 2013; Jake et al. 2015). High alpine plant communities face a disproportional risk from species migration, as range-restricted species have limited abilities to locate new suitable habitats and also face a reduction in the area of suitable climate (Dirnbock et al. 2011). The risk posed to these communities will largely depend on the ability of lower elevation species to migrate upwards (Jake et al. 2015). High alpine forests, which are mainly temperature restricted, have already started intruding into sensitive alpine communities (Dirnbock et al. 2011). Understanding the movement of treelines is essential to better identify areas where endemic species may be at higher risk under future climate change. In addition, large-scale vegetation changes can also affect ecosystem services such as carbon sequestration and storage (Epstein et al. 2012).

Climate-limited treelines are found on the edge of habitats where the life form of 'trees', regardless of species, are no longer capable of growing past a certain elevation or latitude due to a lack of physiological tolerance to the local conditions (Jørgensen 2009). Treelines can occur either as abrupt boundaries between forest and non-forest vegetation or as transition zones where trees progressively become smaller and can be scattered with a combination of young trees and old dwarf trees (Grace et al. 2002; Jørgensen 2009). Treelines are predominantly located in cold areas of high elevation or latitude and are often restricted by cold temperatures during the growing season (Paulsen and Körner 2014). They can also be restricted by other climatic and non-climatic factors, such as a lack of moisture, fires, rock falls or human land use, although these factors diminish in importance at global scales (Paulsen and Körner 2014). In this review, we focus on climatically limited treelines. These can be categorised into two main groups; elevational treelines, which are those existing at higher elevations created by climate gradients up the slope of a mountain, and latitudinal treelines, which indicate the uppermost latitudinal threshold of where trees are capable of establishing.

Treeline ecosystems have experienced more rapid rates of warming compared to the global average due to polar amplification and the above-average warming experienced in the world's mountain ranges (Catalan et al. 2002; Grace et al. 2002; Walker et al. 2006; Nogués-Bravo et al. 2007; Bhatt et al. 2010; IPCC 2014). Being primarily limited by cold temperatures, improved growing conditions associated with climate change could trigger a rapid advancement of treelines (Grace et al. 2002). Treeline ecosystems have previously shown changes in composition, density and extent of species distribution as temperatures and patterns of precipitation have been altered by climate change (Grace et al. 2002; Harsch et al. 2009). The rapid increase in temperature across these ecosystems is believed to be the primary driver as to why more than half of the worlds studied treelines have shown signs of elevational and latitudinal expansion during the past decades (Harsch et al. 2009).

Global warming is expected to have a significant impact on treelines even under a moderate warming scenario, as an increased global average temperature of $2^{\circ} \mathrm{C}$ has been linked to an expansion of the extent of forest in the arctic by up to $55 \%$ (Kaplan and New 2006). Models of future treeline advances are strongly influenced by paleoclimatic records and their correlation to historic treeline positions (Feurdean et al. 2016; McGlone et al. 2019). Several of these records show that treelines have historically been located at higher elevation compared to their current positions, and that the upward migration of forests correlate with periods of warmer climate (Salzer et al. 2013; Feurdean et al. 2016). Studying treeline positions during longer timescales, such as throughout the Holocene, is important not only to better predict the response of treelines to modern climate change (McGlone et al. 2019), but also as they may be capable of capturing treeline advances or depressions occur at longer timescales (Salzer et al. 2013).

The advancement of treelines can have negative consequences for adjacent high alpine and arctic vegetation (which are typically inherently restricted in their geographic range) and could potentially cause significant changes to the carbon dynamics of these ecosystems (Epstein et al. 2012). With vegetation shifts occurring at such a large scale it is essential to better understand the patterns of these movements as well as the climatic factors at play, as knowledge of these drivers will assist in predicting how treelines will respond to future climate change. In this review we only consider changes to the treeline and not changes to either the timber- or forest-line. There is 
an important distinction between these in that the treeline delineates the upper limit of where trees exist, while the timber- and forest-line delineates the upper edge of closed montane forests (Jørgensen 2009). Several definitions have been utilized in the literature to describe the treeline, and while some base the definition purely on the height of the tree (usually 23m) (Baker 2007; Ward 2016), others use multiple parameters such as height, cover and crown size (Körner 1998).

In this review we consider all treeline studies regardless of the definition used by the respective author as long as the authors are referring to established adult trees and not young seedlings. The review contains both a qualitative and quantitative review of modern treeline migration. The specific aims of this review are to (I) identify the biophysical characteristics of treelines, (II) map where treeline migration has occurred during the past century, (III) assess what drives treeline migration, and lastly (IV), identify the potential implications treeline migration may have on ecosystem carbon storage. Our review reveals that the majority of studied treelines around the world are moving to higher elevations and latitudes. In addition, some of these treelines are expanding at a rapid rate. We furthermore discuss what implication these changes have on the local carbon budgets and the potential role of treeline migration as a positive feedback effect for future climate change.

\section{Methods and Material}

\subsection{Literature review}

To ensure a high-quality review of the literature on modern treeline migration we conducted a comprehensive search of peer-reviewed journals. The search was conducted in Scopus, Web of Science, Google Scholar as well as the University of Queensland Library service. Key search terms, such as "treeline" and "treeline" migration, advance, movement, encroachment, recession and change were used, as well as various grammatical suffixes of these words. The reference section for each article was scanned to identify additional articles that were not identified in the database search. Lastly, book and thesis chapters were used sparingly where there was a lack of published peer-reviewed information on a topic.

\subsection{Database creation}

Treeline studies were identified using the journal search tool in Scopus applying the following search key: TITLE-ABS-KEY (treeline* OR tree-line* OR "tree line" AND migrat* OR advanc*) AND (LIMITTO (SUBJAREA, "AGRI") OR LIMIT-TO (SUBJAREA, "ENVI") OR LIMIT-TO (SUBJAREA, "EART")). This search yielded 533 search results, for which abstracts were perused to identify relevant literature. In addition to the search in Scopus the reference list of all relevant publications was reviewed to identify additional literature of interest. The literature search was conducted between June 2018 to March 2019. This review only concerns changes in the upper treeline positions as such changes represent a shift in the distribution of ecosystems rather than a change in ecosystem composition.

Hence, this review includes all identified articles examining the changes to the upper treeline, regardless of the definition of the treeline used by the authors. Articles measuring other changes such as tree-density, seedling establishment, radial growth or expansion of species which does not make up the upper treeline were excluded. Furthermore, papers describing a timber- or forest-line were excluded from this review. A significant number of articles identified by Harsch et al. (2009) were also incorporated in our database, on the basis that they fit our selection criteria. From the Scopus search and the review of reference lists a total of 142 published articles were selected to be included in the database. These 142 journal articles included a total of 477 locations where treeline positions have been measured.

Tree growth can respond quickly to favorable changes in temperature and precipitation and may in addition cause seedlings to establish high above the existing treeline. However, a few adverse summers have the potential to kill new re-growth achieved over favorable preceding seasons (Körner and Riedl 2012). These changes do not necessarily represent a change to the treeline, and seedlings above the treeline may therefore not indicate a climatic shift in treeline position but may simply be the result of short-term changes in temperature or precipitation. Treeline studies were therefore only included if the trees at the upper limit had matured to at least $2 \mathrm{~m}$ unless they were of krummholz structure. Treelines were identified as advancing if they increased either in an elevational or latitudinal 
direction while receding treelines (1.69\%) were listed as not advancing. Overall, 66\% of studied treelines had increased in either elevational or latitudinal extent, while $32 \%$ were either unchanged or receding.

A range of different information was recorded in the database such as the method of measurement, timeframe of study, and longitudinal and latitudinal location of treeline (where data was not explicitly available, Google Earth was utilised to indicate an approximate location of the site). We also recorded elevation, aspect, total and/or annual change in elevation or latitudinal extent, treeline form, the family of tree species, the period of most significant change of movement, country of study and recorded disturbances. These data were presented as recorded by the authors and cells were left blank in the database when this information was not reported in the publication. The duration of the study was measured in different ways depending on the type of study: (1) for repeat photography measured between the first and last photography taken; (2) for transect studies measured as the first and last year of the survey; and (3) for dendrochronology measured as the age of the oldest tree indicating a past treeline and the age of the oldest tree at the current treeline position. Age was left blank where no information in age was provided.

The rate of change or total shift in elevational or latitudinal position was noted for studies where information was provided (49.52\%), as well as for a few studies that measured the reduction of forest openings at the treeline (1.21\%). The methods to present such data varied significantly between studies, and while some studies only reported an average increase (usually for larger areas), others exclusively reported the maximum change in elevation or latitude. Where both these values were presented only the average change in elevation was included under the total change in elevation, while the maximum value was entered as the maximum change in treeline position. Aspects were recorded for each datum point as this has the potential to influence other parameters that affect growth, such as precipitation, temperature, solar insulation and the presence of snow and permafrost (Danby and Hik 2007). These were after that classified as Neutral (E\&W), Cold (N in Northern hemisphere and $\mathrm{S}$ in Southern hemisphere) or Warm ( $\mathrm{S}$ in Northern hemisphere and $\mathrm{N}$ in Southern hemisphere).

\section{Results and Discussion}

\subsection{Biophysical environment of treelines}

A strong correlation has been identified between seasonal mean air temperatures and tree growth near the treeline (Gehrig-Fasel 2007). Tree-growth requires a minimum growing season length of 94 days, defined as all days having a mean daily temperature of $>0.9^{\circ} \mathrm{C}$ with the mean reaching at least $6.4^{\circ} \mathrm{C}$ across all days (Paulsen and Körner 2014). Three elements support the widely accepted theory of temperatures being the primary control for treeline positions: (1) the global relationship between temperature isotherms and treeline positions (Körner and Paulsen 2004); (2) the correlation between historical changes in treeline positions and temperature change (Lloyd and Graumlich 1997; Carrara and McGeehin 2015); and (3) recent advancement of treelines associated with global warming (Harsch et al. 2009).

Treelines appear at different elevations and latitudes depending on the local climatic characteristics. In the northernmost Sweden $\left(68^{\circ} \mathrm{N}\right)$ the treeline can be found at $700 \mathrm{~m}$ above mean sea level (a.s.l) (Körner and Paulsen 2004). In the Swiss Alps $\left(46^{\circ} \mathrm{N}\right)$, the treeline are located at a considerably higher 2200m elevation (Coops et al. 2013). In countries closer to the equator, such as Nepal $\left(28^{\circ} \mathrm{N}\right)$ and Mexico $\left(19^{\circ} \mathrm{N}\right)$, the treelines are instead located at a much higher elevation of around $4000 \mathrm{~m}$ a.s.l. (Körner and Paulsen 2004). Treelines in the southern hemisphere are situated at overall lower elevations compared to their northern equivalent latitudes, and where treelines at around $35^{\circ} \mathrm{N}$ are found at approximately 3000-3500 $\mathrm{m}$ elevation the southern equivalent treeline $\left(\approx 35^{\circ} \mathrm{S}\right)$ is located at an elevation of about $2000 \mathrm{~m}$ (Cieraad et al. 2014). There is, however, no clear evidence that the thermal threshold is lower in the southern hemisphere, as treelines across the world (including the Southern hemisphere) appear at around the same annual mean growing season temperature (Körner and Paulsen 2004; Cieraad et al. 2014)

It is not only the average temperatures that can influence treeline position; the timing of the onset and end of the growing season is also critical (Coops et al. 2013). Several additional biotic and abiotic factors have been identified to limit the growth of trees near the treeline, including both inadequate 
snow protection (Esper and Schweingruber 2004) and too heavy snow loads (Autio 2006), insufficient effective temperature sum and length of the growing season (Autio 2006), lack of precipitation (Aune et al. 2011), competition (Treml and Chuman 2015), incoming solar radiation (Bader et al. 2007), permafrost and depth of the active soil layer (Wilmking et al. 2012), extreme soil temperatures (Autio 2006), moisture availability (Andersen and Baker 2006; Autio 2006), fires (Butler and Dechano 2001), frost events occurring during the growing season (Autio 2006; Coop and Givnish 2007), high wind speeds (Autio 2006; Dinca et al. 2017), and insect outbreaks (Hofgaard et al. 2013). A recent study by Tingstad et al. (2015) conducted in southern Norway found seedlings planted in alpine areas above the current treeline establish at a significantly higher rate compared to seedlings planting in boreal regions, indicating competition may be a more significant determining factor of tree establishment than low temperatures. Competition may, however, not always be purely negative, as the shade provided by neighboring trees can protect seedlings from high incoming solar radiation experienced at nearequatorial treelines and thereby outweighing the competitive effects (Bader et al. 2007).

While there are several published studies of vegetation shifts in treeline regions, there are many aspects of these dynamics that are still not well understood. Trees located in the same area can, for example, exhibit a different growth response when exposed to the same change in climatic factors depending on the local biophysical setting. As an example, Bunn et al. (2007) identified that trees in the same location responded differently to trends in precipitation and temperature depending on the local soil moisture availability. Trees experiencing greater water stress reacted more strongly to rainfall while trees with ample water supply showed a higher response of growth with temperature changes. This highlights that while temperature may be the limiting factor for most treelines an increase in temperature may cause reduced growth and survival rates in already water-stressed sites (Lloyd and Fastie 2002; Wilmking and Juday 2005). Hence, increased temperatures may potentially only accelerate treegrowth in areas with sufficient moisture availability. The influence of increased temperatures will have on tree-growth may, therefore, be dependent on the local topography (Nicklen et al. 2016) and moisture availability (Bunn et al. 2007), as warmer temperatures may exacerbate moisture stress. Other relationships, such as snow cover, are somewhat more challenging to understand and may present a fine line between promoting tree establishment and limiting it. While seedlings can benefit from an increase in snow cover, as some snow can offer protection by insulating the seedlings (Kharuk et al. 2009), too much snow can increase the risk of physical damage to fragile young trees (Autio 2006).

Recent warming trends have not only increased the average and maximum recorded temperatures but also increased the length of the growing season (Zhang et al. 2018), resulting in an extension of the growing season by up to 20 days in some regions (Linderholm 2006; Blinova and Chmielewski 2015). The increase in temperature is strongly correlated to the growing degree day (GDD), which is a heat index based on the annual sum of daily temperatures above a pre-defined threshold, often set at the minimum growth temperature for the species. The GDD has increased rapidly in some areas, with GDD increasing by up to 233 degree days in Finland since the 1960s (Kauppi et al. 2014). Such an increase can lead to several changes to the phenology of trees, such as earlier leaf unfolding, earlier spring bloom and later leaf fall, as well as changed elevational and latitudinal positions of treelines (Linderholm 2006). While warmer temperatures have the potential to increase the length of the growing season, an earlier transition from snow to rain increases the risk of frost damage to plants. An increase in the frequency of days with sub-zero temperatures during early spring growth might outweigh many of the positive effects associated with earlier snowmelt (Wipf et al. 2009).

\subsection{Mapping recent treeline migrations}

The analysis presented here builds on the most recently published meta-analysis of global treeline movements by Harsch et al. (2009). A database was created based on 142 published papers, containing a total of 477 treeline sites from 24 countries, spanning across both the northern and southern hemisphere (Figs. 1 - 3). Overall, there was a sharp skew towards treeline studies in the northern hemisphere, with only 16 treelines in the database located in the southern hemisphere (Table 1). We noted that $66 \%$ of all studied treelines have shown increased elevational or latitudinal positions. Only $1 \%$ of treelines were 
recorded to be receding. For the majority of receding treelines identified in this study the recession can be attributed to a reduction in stem height caused by foliage loss and stem breakage of the uppermost tree making up the treeline (Öberg and Kullman 2012). In instances where tree-height is used to define the treeline a reduction in height of the uppermost tree has the potential to reduce the elevation of the treeline even when the past treeline marker is still alive. There is a range of different factors that could cause a decline in the health of individual trees which can eventually lead to a treeline retreat. These may be driven by the onset of drought conditions (Öberg and Kullman 2012) or other non-climatic factors such as beetle or moth outbreaks (Van Bogaert et al. 2011).

The vast majority of recorded treeline sites $(n=$ 438) addressed elevational treeline advances (trees moving up a mountain or hill to higher elevations), while 39 addressed latitudinal advances (trees having an increased upper latitudinal range regardless of their elevation) (Table 1). While elevational treelines were more prone to migrate compared to latitudinal treelines (67\% vs $56 \%$ ), latitudinal treelines moved significantly further, on average increasing by $47 \pm 82.4$ meters per year compared to $1.42 \pm 2.44$ meters per year for elevational treelines. This is likely due to easier dispersal of latitudinal trees across landscapes, as well as the sharp temperature isotherms occurring over shorter temporal distances in mountain regions as well as the elevational gradient acting as a barrier for seedling dispersal. Apart from the apparent difference in movement between elevational and latitudinal treelines, there was little to indicate that trees at a certain latitude or elevation were more likely to migrate. While a considerably lower percentage of treelines showed movements in the southern hemisphere (31\%) compared to the northern hemisphere (67\%) (Table 1), the lack of samples from the southern hemisphere means that no definitive conclusion can be made as to if the external validity of these results.

There are still a substantial number of treelines that have not migrated to higher elevation or latitudes. This could partially be due to time-lags in the response of trees to warmer temperatures, as many species are not capable of moving at the same rate that temperatures are increasing (Svenning and Sandel 2013). We found that a higher proportion of treeline studies monitoring changes occurring during the past 50 years failed to find signs of treeline movements compared to those studying treeline movements over a longer timeframe. In our database, the duration of monitoring was therefore recorded, as this may influence the detected treeline response to climate change.

Table 1 Summary of recorded treeline movements and associated parameters influencing the probability of treeline migration.

\begin{tabular}{|c|c|c|c|c|}
\hline Category & Sub-category & $\begin{array}{l}\text { Total number } \\
\text { ( } n, \% \text { of total) }\end{array}$ & $\begin{array}{l}\text { Has moved } \\
(n, \%)\end{array}$ & $\begin{array}{l}\text { Has not } \\
\text { moved }(n, \%)\end{array}$ \\
\hline Total data & & $477(100 \%)$ & $316(66 \%)$ & $161(34 \%)$ \\
\hline \multirow{2}{*}{ Hemisphere } & Northern & $461(97 \%)$ & $311(67 \%)$ & $150(33 \%)$ \\
\hline & Southern & $16(3 \%)$ & $5(31 \%)$ & $11(69 \%)$ \\
\hline \multirow{2}{*}{ Treeline type } & Elevational & $438(92 \%)$ & $294(67 \%)$ & $144(33 \%)$ \\
\hline & Latitudinal & $39(8 \%)$ & $22(56 \%)$ & $17(44 \%)$ \\
\hline \multirow{3}{*}{ Treeline form } & Abrupt & $38(8 \%)$ & $18(47 \%)$ & $20(53 \%)$ \\
\hline & Diffuse & $190(40 \%)$ & $132(69 \%)$ & $58(31 \%)$ \\
\hline & Krummholz & $66(14 \%)$ & $33(50 \%)$ & $33(50 \%)$ \\
\hline \multirow{4}{*}{ Aspect } & Warm & $122(26 \%)$ & $77(63 \%)$ & $45(37 \%)$ \\
\hline & Neutral & 65 (14\%) & $40(61 \%)$ & $25(39 \%)$ \\
\hline & Cold & $108(22 \%)$ & $72(67 \%)$ & $36(33 \%)$ \\
\hline & All & $71(15 \%)$ & $60(85 \%)$ & $11(15 \%)$ \\
\hline \multirow{3}{*}{$\begin{array}{l}\text { Vascular seed } \\
\text { plant group }\end{array}$} & Angiosperms (a) & $164(34 \%)$ & $91(55 \%)$ & $73(45 \%)$ \\
\hline & Gymnosperms (g) & $303(64 \%)$ & $217(72 \%)$ & $86(28 \%)$ \\
\hline & Combination of Angiosperms and Gymnosperms & $4(1 \%)$ & $4(100 \%)$ & o $(0 \%)$ \\
\hline \multirow{8}{*}{$\begin{array}{l}\text { Tree family } \\
\text { (vascular } \\
\text { seed plant } \\
\text { group) }\end{array}$} & Betulaceae (a) & $131(27 \%)$ & $75(57 \%)$ & $56(43 \%)$ \\
\hline & Cupressaceae (g) & $2(0 \%)$ & $2(100 \%)$ & $\mathrm{o}(\mathrm{O} \%)$ \\
\hline & Ericaceae (a) & $2(0 \%)$ & $2(100 \%)$ & o (o\%) \\
\hline & Fagaceae (a) & $6(1 \%)$ & $1(17 \%)$ & $5(83 \%)$ \\
\hline & Nothofagaceae (a) & $15(3 \%)$ & $4(27 \%)$ & $11(73 \%$ \\
\hline & Pinaceae $(\mathrm{g})$ & $300(63 \%)$ & $215(72 \%)$ & $85(28 \%)$ \\
\hline & Salicaceae (a) & $3(1 \%)$ & $3(100 \%)$ & $\mathrm{o}(\mathrm{O} \%)$ \\
\hline & Combination of families or unknown family & $18(4 \%)$ & $12(67 \%)$ & $4(33 \%)$ \\
\hline
\end{tabular}




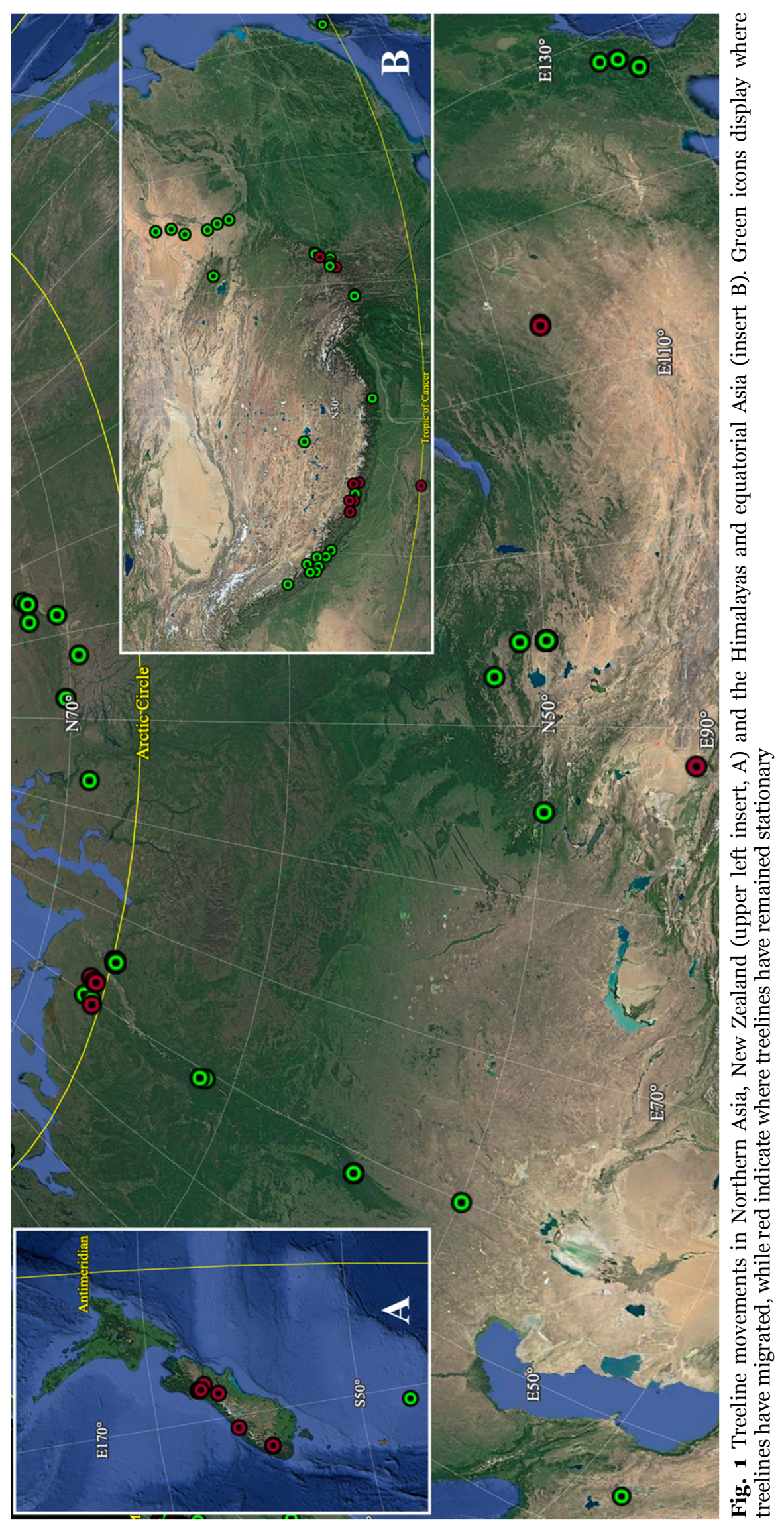




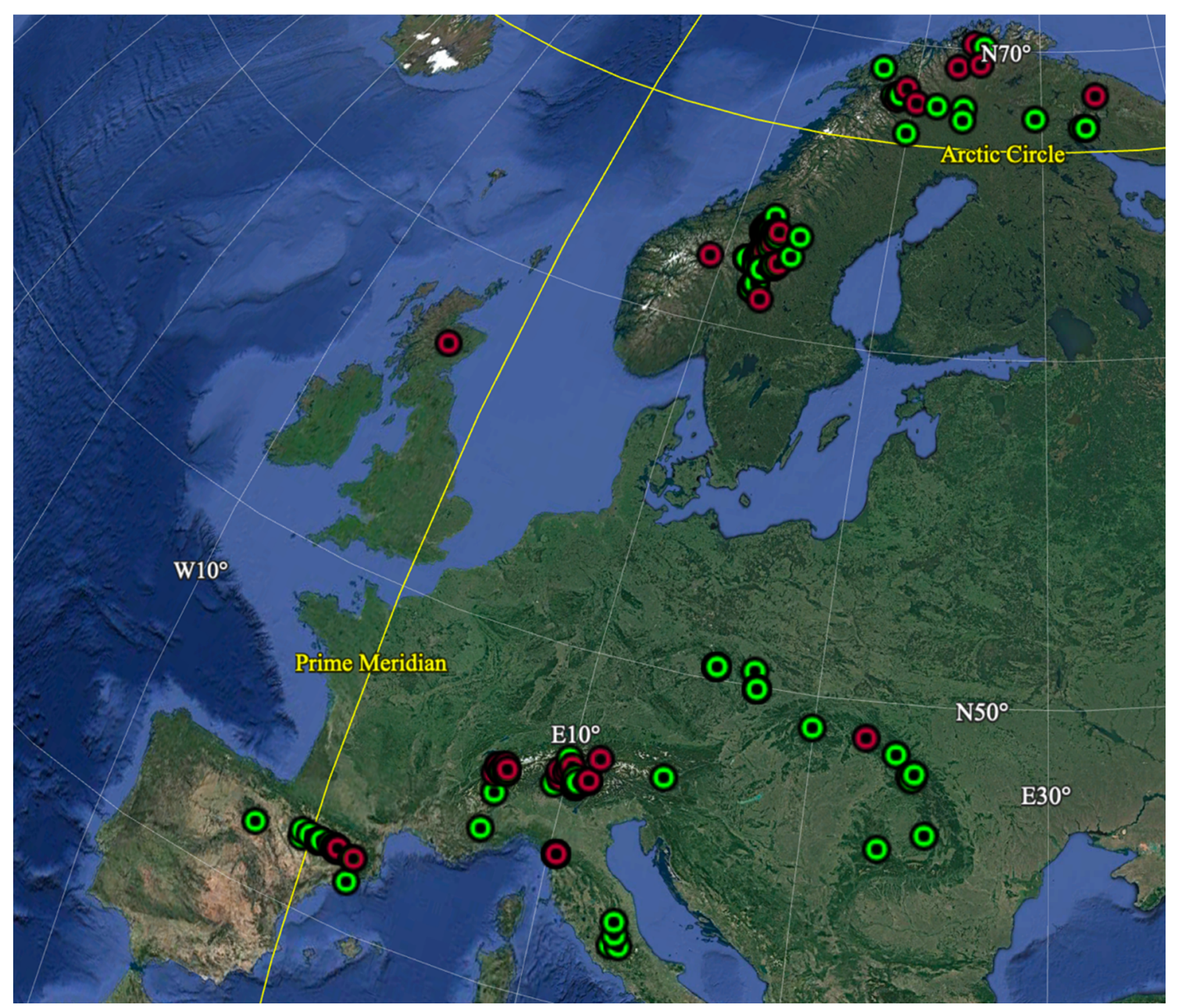

Fig. 2 Treeline movements in Europe. Green icons display where treelines have migrated, while red indicate where treelines have remained stationary.

Treelines were also classified based on their physical properties, as the structural characteristic of treelines can influence how they respond to climate change (Harsch et al. 2009; Compostella and Caccianiga 2017). The type of treeline was recorded as either: abrupt, indicating a sharp transition between tree and non-tree vegetation; diffuse where gradual transition zones occurred, or krummholz where trees have a stunted growth form (Harsch et al. 2012). Krummholz trees are often found at higher elevations than trees of standard growth form and can be an indicator of very harsh growing conditions. These trees may not be representative of true tree-growth temperature restrictions as they create their own local micro-climate, which is warmer than that of other treeline situations (Körner and Paulsen 2004). It could, therefore, be argued that krummholz trees should be excluded when studying treelines as they do not necessarily follow the growing temperature limit as defined by Paulsen and Körner (2014). However, these trees were still included in our database, because while the temperature of the treeline may differ, they are still primarily climate restricted, and a change in the uppermost position of these trees will still represent a change in the limiting growing conditions.

We found that diffuse treelines are more likely to migrate as compared to abrupt and krummholz trees (Table 1). Diffuse treelines can be caused by a gradual transition in suitable climate for tree-growth. A sharp boundary between tree and non-tree vegetation may be due to other factors that limit the establishment or survival of seedlings above the present treeline. Examples of this would be in cases where poor seedling dispersal in combination with topographic barriers limit upwards establishment (Shiyatov et al. 2005), or where there are ecological requirements for sheltered microsites (i.e., frost protection) to enable 


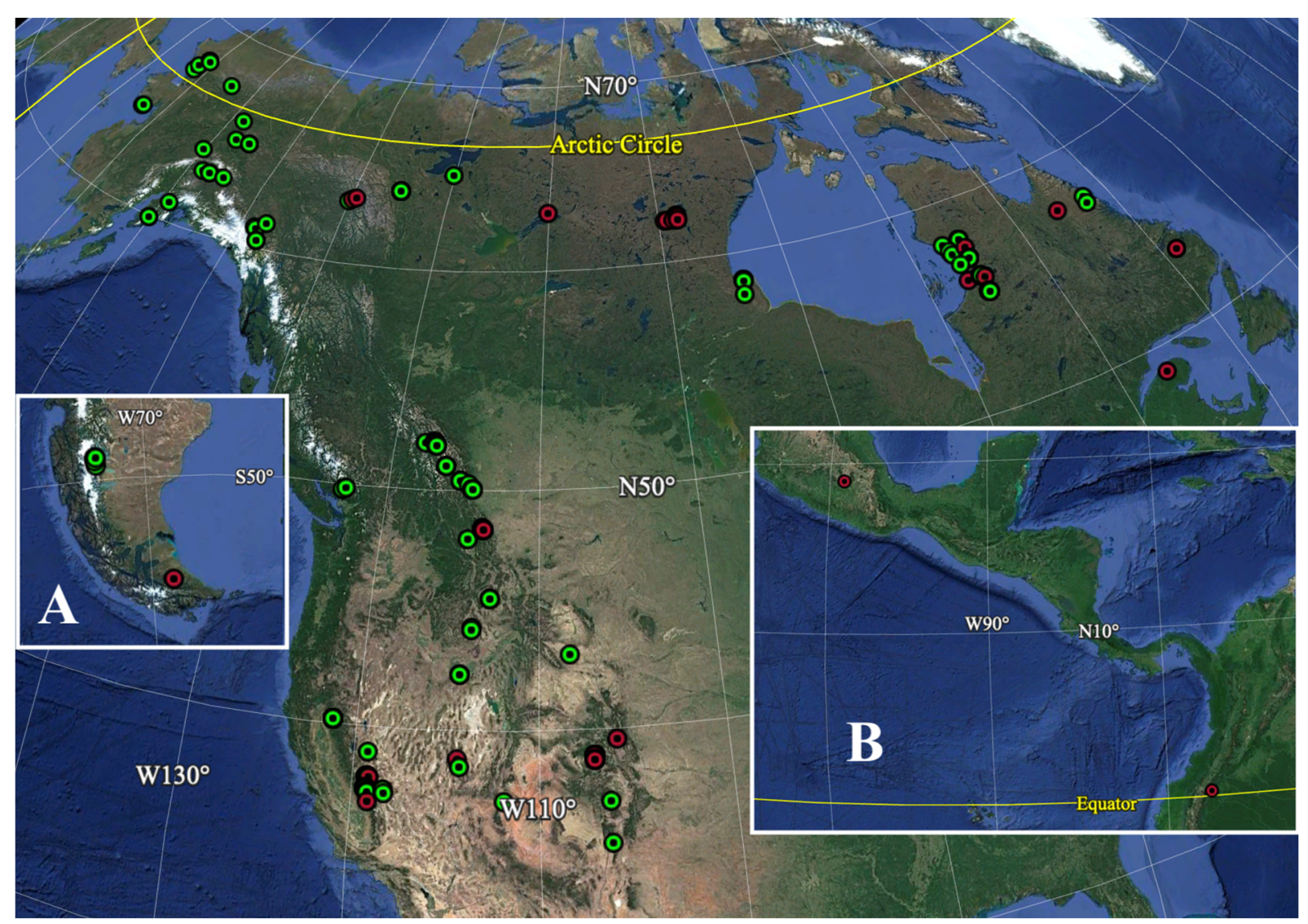

Fig. 3 Treeline movements in North, and South (insert A) and Central (insert B) America. Green icons display where treelines have migrated, while red indicate where treelines have remained stationary.

successful seedling survival (Harsch et al. 2012).

The aspects of the treelines were also recorded in our analysis, as this will influence the amount of sunlight a site receives, which in turn will affect moisture availability, microclimate, and direct energy input. As sites were located both in the northern and southern hemisphere the location was classified either as cold when facing away from the sun, warm when directly oriented to the sun, or neutral if in an eastern or western aspect. Some studies measured and reported movement on all sides of a mountain rather than per aspect, and these were then classified as 'all'. In areas where all aspects were studied, treelines were significantly more likely to show signs of expansion. Treelines measured on all aspects advanced in $85 \%$ of cases, compared to those measured at a single aspect which advanced between $61 \%-67 \%$ (Table 1). This result is expected as the more extensive the area studied the more likely evidence of change would be detected. Treelines appear to have reacted to warming in a similar manner regardless of aspect. Our result does, however, highlight that movements may be overlooked if only one aspect of a mountain is considered. The dominant tree family composing the treeline was also recorded, with most trees belonging to either the Betulaceae or Pinaceae families. There is no measurable difference as to how these two tree families have responded to climate change, however, there is a clear difference if classifying samples as angiosperms and gymnosperms. While only $55 \%$ of angiosperms have increased in extent, $72 \%$ of gymnosperms have increased in elevation or latitude. It is here important to point out the overrepresentation of gymnosperms in the dataset, with angiosperms only representing $34 \%$ of measured treeline sites compared to the $64 \%$ of gymnosperm sites.

Despite temperatures increasing at a global scale, treeline advancement has not occurred uniformly across the world. This may be due to the substantial seasonal and spatial variability of global temperature changes (Anderson 2012). Considering treeline positions are primarily determined by the temperature during the growing season (Paulsen and Körner 2014), it would be expected for summer temperatures to be the main parameter affecting treeline advance. Despite this, Harsch et al. (2009) 
found no relationship between increased summer temperatures and treeline advance. Instead, from their analysis, it seems that increased winter temperatures were the more influential variable in determining treeline movement. These results may be explained by the fact that treeline movement is caused by the survival of seedlings above the present treelimit rather than by overall tree-growth, for which milder winter temperatures may be a more critical factor (Weih and Karlsson 2002). While consideration was taken to elevation, treeline species and distance to the ocean, changes in precipitation were not analyzed by Harsch et al. (2009), which could potentially be an essential factor if warmer temperatures are combined with a reduction in moisture availability. A lack of available water may prevent trees from establishing (Mamet and Kershaw 2012; Öberg and Kullman 2012), hence limiting the potential of treelines to migrate.

\subsection{Drivers of treeline migration}

Advances of treelines are primarily dependent on the successful survival of new seedlings, which can be influenced by a range of factors (Holtmeier and Broll 2007). Climate change can affect the rate of seedling success through warmer summers which can improve seed viability and emergence of seedlings, and by increased winter temperatures which cause reduced mortality rates of trees (Kullman 2007). A relationship between the advance of treeline positions and increased winter temperatures have been observed at a global scale, where treelines located in areas experiencing a high level of warming during winter being observed to be more likely to advance than other treelines (Harsch et al. 2009). In addition to an increased upwards and latitudinal extent of trees, forests have shown changes such as increased radial growth (Paulsen and Weber 2000), more successful seedling recruitment and thereby also increased forest densities (Danby and Hik 2007). Some of these changes may be due to the general trend towards earlier onset of spring-thawing across the Arctic, causing an earlier start of the growing season (Sitch et al. 2007).

The patterns of tree establishment are, however, not homogenous. In some locations, there has been an overall increase in tree establishment during the past century, but the rate of that change has slowed down in more recent decades (Alftine et al. 2003;
Holtmeier and Broll 2011). This again indicates that despite the relationship between treelines and temperature identified by Körner (1998) temperatures is still only one of several parameters influencing treeline migration. The complexity of the relationship between temperature and growth has been highlighted by some treelines displaying an overall a negative growth-trend when exposed to increased temperatures (Lloyd and Fastie 2002; Wilmking et al. 2004; Kullman 2005). Treelines around the world are, besides, comprised of a range of different species, whose successful regeneration and survival of young may be influenced to a varying degree by increased temperatures (Holtmeier and Broll 2007).

Trees are not expected to migrate uniformly to higher latitudes and elevations with increased temperature. Factors like topography, local site conditions and the influence of natural and anthropogenic disturbances may override the positive effects caused by increased temperatures (Holtmeier and Broll 2007). Warmer temperatures may, in some instances also lead to increased snowfall, causing increased snow load and potentially destroying the crown and branches of trees (Autio 2006). In addition to these findings some studies argue that non-climate related factors, such as anthropogenic disturbances, grazing activity, geomorphological processes and moth outbreaks may be more influential on patterns of treeline establishments in certain areas than recent temperature changes (Gehrig - Fasel et al. 2007; Van Bogaert et al. 2011; Ameztegui et al. 2016). Local landforms and small-scale differences in topography control site-specific conditions, which may be detrimental to predicting future tree establishment. Rugged mountain terrain may for example limit treeestablishment due to debris slides and avalanches, while convexities in steep eroded terrains may offer safe sites where trees can establish up to the climatically induced treeline (Fig. 4) (Holtmeier and Broll 2012). Identifying microsites facilitating treeestablishment can, therefore, be an essential predictor of tree-growth in topographically rough terrains (Holtmeier and Broll 2012).

As already summarized by Harsch et al. (2009) there are multiple reasons as to why treelines may not respond linearly to warmer temperatures, such as the time-lag between warming and response of movement, past disturbances or internal variations in temperatures. Determination of treeline movement 


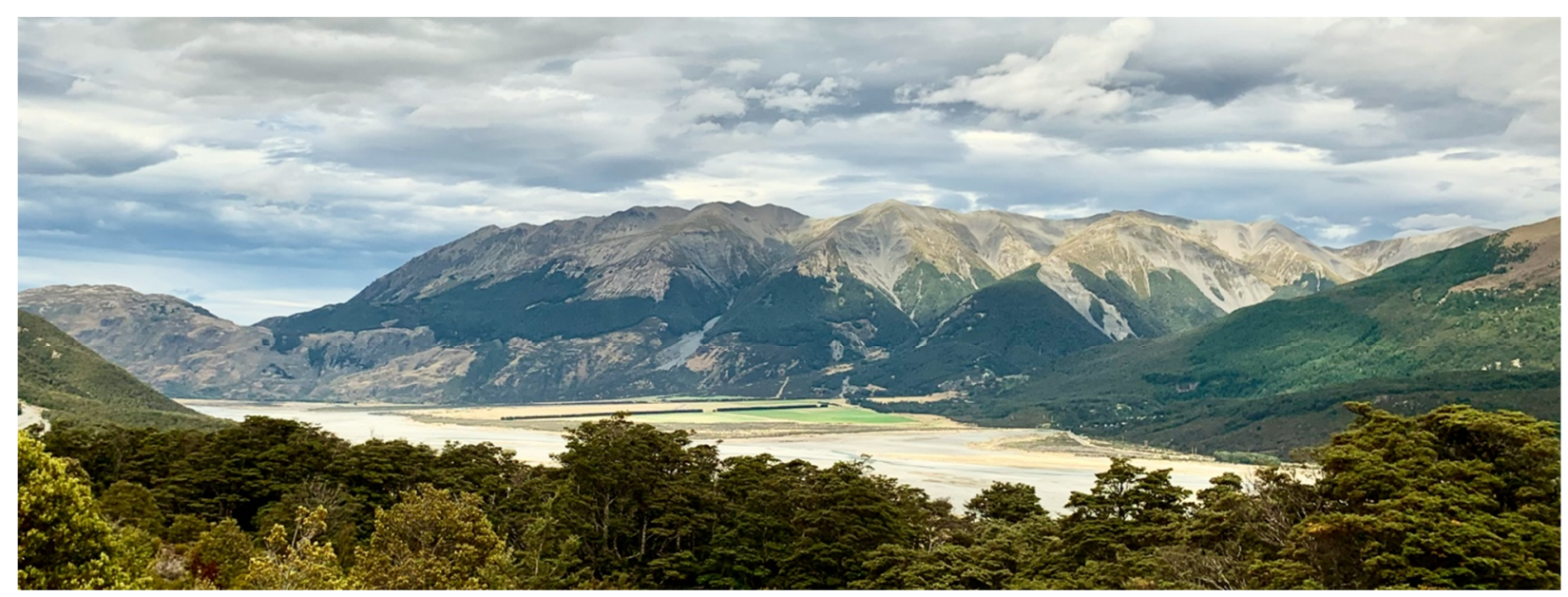

Fig. 4 Treelines existing at various elevations in Arthurs Pass, New Zealand. Treelines can be found below their climatic threshold in areas where topography and rockfalls prevent trees from establishing further upslope.

can also be limited by the coarse scale of some remote sensing data which may prevent detection of advancement. Several attempts have been made at modelling the response of treeline movements under future climate change. Vegetation modelling is dependent on accurately being able to identify parameters that are important for seedling establishment and survival. Treeline modelling is therefore based on a broad spectrum of climatic and non-climatic parameters (Dullinger et al. 2004). Accurately identifying climatic drivers of treeline migration may be difficult in areas subject to heavy human disturbance, such as the European Alps. Many treelines are still located below their climatic limit, and it can be difficult to separate advancement caused by climate change from re-establishment of trees after the cessation of clearing and intense grazing (Camarero and Gutiérrez 2004, Ameztegui et al. 2016). Capturing the wide range of influencing climatic parameters in models can also be difficult due to the many local variations in climatic parameters which may be important for seedling establishment and survival. For example, Dullinger et al. (2004) modelled treeline migration of Pinus mugo in the Austrian alps only using only water balance in August. In contrast, in the nearby Swiss Alps Vittoz et al. (2008) identified rainfall in October to have a significant influence on treeline migration of Pinus cembra. Similarly, while Holtmeier and Broll (2010) identified strong and persistent wind to limit treeline migration in many areas of both the Alps, North America and the European Subarctic several treeline models exclude this important parameter (Moen et al. 2004, Zhang et al. 2013).
Treelines moving into tundra landscapes may also be restricted by other parameters, such as the presence of permafrost and the ability of the soil to drain (Lloyd 2005). While models predict occurrence of permafrost near these high-latitudinal treelines (Wania et al. 2009, Bonnaventure and Lewkowicz 2012) this type of information is not always taken into account when predicting future distributions of forests (Pearson et al. 2013, Zhang et al. 2013). Again, it is important to consider the individual species response to climatic and non-climatic parameters, as some taxa are highly tolerant to the presence of permafrost, which in those cases need to be taken into account when modelling future distributions (Kruse et al. 2016). In addition to variation in climatic influence between species and locations past human influence has proven to be an important parameter to consider in treeline modelling in areas of anthropogenic disturbance (Wallentin et al. 2008, Ameztegui et al. 2016). Extrapolation of treeline distribution models therefore has to be done with care.

Knowledge of past response of treelines is crucial as this allows for testing the accuracy of treeline modelling. Combining this with detailed analyses of species response to climatic factors and potential for dispersal is required to improve the selection of climatic parameter. Due to the often-slow nature of treeline migration and the more recent capabilities of complex vegetation modelling it is still too early to say how accurate these predictions will prove to be. While all the parameters influencing treeline movements make it challenging to model treeline advancement at a global scale, more precise data on the drivers and limitations of treeline movements are crucial. Not 
only will rates of treeline advance influence the extent to which sensitive alpine and arctic ecosystems are reduced or lost due to increased competition from vascular plants (Dirnböck et al. 2011), they could also have a significant influence on global carbon budgets.

\subsection{Implications for carbon storage}

With latitudinal treelines moving at a faster rate than elevational treelines, forests have started to extend into what was previously tundra landscape. The total above-ground biomass tends to decrease rapidly as the vegetation transitions from forest to non-forest (Schmid et al. 2006; Coops et al. 2013). This can significantly influence the carbon stored in an ecosystem, as more aboveground biomass can lead to greater carbon sequestration. Nevertheless, while an expansion of forests is likely to increase carbon sequestration, some believe that this increased carbon absorption will be offset by other feedback mechanisms (Field et al. 2007). This is primarily due to the range of effects trees can have on the soil dynamics, which can furthermore influence the carbon storage potential of soils. These processes can become to be of particular importance for tundra landscapes, which typically act as great sinks of carbon. These can convert to become net sources of carbon dioxide when vascular plants establish (Cahoon et al. 2012, Parker et al. 2015).

Numerous physical and biological drivers have the potential to influence the carbon balance of ecosystems (Celis et al. 2017). Physical drivers causing alterations to the $\mathrm{CO} 2$ flux include snow cover dynamics influencing the length and onset of the growth season (Hobbie and Chapin 1998; Groendahl et al. 2007; Euskirchen et al. 2012; Lund et al. 2012); changes in temperature (Bergeron et al. 2007; Groendahl et al. 2007; Cahoon et al. 2012; Lund et al. 2012), altered moisture conditions (Sitch et al. 2007; Euskirchen et al. 2012; Natali et al. 2015) resulting in oxidation of soil carbon; and changed nutrient availability (Christensen et al. 1997; DeMarco et al. 2014; Salmon et al. 2016). Biological drivers causing alterations in the carbon balance include changes in plant communities (Cahoon et al. 2012, Epstein et al. 2012; Parker et al. 2015); grazing activity (Kelsey et al. 2016), soil fungi composition (Fernandez and Kennedy 2016); and changes in species performance (Oberbauer et al. 2013).

It remains unclear how treeline expansion will influence ecosystem carbon budgets in tundra regions. Soil carbon stocks are strongly influenced by the above ground vegetation composition, with the species carbon input and litter quality being associated with the carbon dynamics (Djukic et al. 2010). Three main hypotheses have been suggested: (1) increased above-ground biomass will lead to greater carbon sequestration and storage (Hobbie and Chapin 1998; Sturm et al. 2001; Epstein et al. 2012), with more litter increasing both soil and aboveground carbon storage (Qian et al. 2010); (2) shrub expansion will cause a net release of carbon, as shrubs increase the rate of respiration and cause more rapid soil carbon turnover (Wilmking et al. 2006; Cahoon et al. 2012; Parker et al. 2015); or (3), these changes will balance themselves out, leading to no change in the overall carbon storage of the ecosystem (Hobbie and Chapin 1998; Ziegler et al. 2017). The net effect of carbon storage in tundra ecosystems will be dependent on interactions amongst climate change, shrub canopy development, and the soil microclimate (Cahoon et al. 2012). The increase of trees in tundra ecosystem often causes a reduction in plants associated with tundra landscapes, such as grasses, mosses and lichens (Dawes et al. 2015). Changing vegetation composition from tundra to forest affects both the overall carbon storage potential as well as the proportion of above and below ground carbon pools.

A shift from generally low-productive tundra heath to deciduous shrubs with higher productivity may lead to a loss of soil carbon (Parker et al. 2015). For example, studies in Sweden and Alaska have shown that tundra landscapes store significantly greater amounts of carbon compared to adjacent forests (Wilmking et al. 2006; Hartley et al. 2012). Shrubs and forests do in general have greater above ground biomass compared to tundra. However, they also have significantly lower below-ground carbon storage, with the below ground storage capacity being low enough for forest ecosystems to hold overall less carbon (Wilmking et al. 2006; Parker et al. 2015; Sørensen et al. 2017). The reduction in below ground carbon is likely due to carbon stocks under forests and shrubs being metabolised and returned to the atmosphere through respiration at a substantially faster rate, resulting in lower levels of carbon sequestration in the soil (Hartley et al. 2012; Parker et al. 2015). This response is referred to as a positive priming effect, and primarily occurs during the middle 
of the growing season when the high plant productivity stimulates decomposition of old soil organic matter (Hartley et al. 2012). An equally powerful effect is transpiration of water by trees that lowers soil water tables (e.g., Woodward et al. (2014)) and thereby permits oxidation of soil carbon. However, it is still unclear how the net carbon pool reacts to these vegetation changes as an increase in the above-ground biomass will amplify the potential above-ground carbon pool of alpine areas (Epstein et al. 2012). In addition, novel plant communities caused by species migration may react differently to climate stressors, which can alter the carbon sequestration capacity of the vegetation ( $\mathrm{Au}$ et al. 2020).

Several recent publications examining changes in carbon dynamics caused by a shift in vegetation composition indicates that expansions of shrubs and trees are in some areas creating a net loss of carbon pools, as the increase in above-ground biomass is not sufficient to compensate for the loss of carbon occurring from the soil (Wilmking et al. 2006; Iain et al. 2012; Parker et al. 2015). The carbon dynamics of ecosystems are however complex, and the same ecosystem can act both as a source and a sink of $\mathrm{CO}_{2}$ depending on the mostly seasonally determined climatic conditions prevalent when carbon dynamics are measured (Grogan and Chapin III 1999; Euskirchen et al. 2012; Celis et al. 2017). There are still debates for how the transition from net sequestration to net emissions of these ecosystems can be predicted. Grogan and Chapin III (1999) observed an almost direct positive relationship between soil temperatures and ecosystem respiration, supporting the theory that warmer soil temperatures during winter promote an increased release of soil carbon. This relationship may not be universal as Euskirchen et al. (2012) found the number of growing degree days in early spring to be the strongest determiner of $\mathrm{CO}_{2}$ flux, indicating spring temperatures to be significant in predicting when ecosystems will shift from acting as a carbon sink to source. The added complexity of vegetation changes makes this prediction even more complicated, meaning the net effect treeline migration and global warming have on overall ecosystem carbon dynamics becomes near impossible to quantify, and in particular so at larger scales.

\section{Conclusion}

The majority of the worlds measured treelines are showing signs of increased elevational and latitudinal extent. These movements are important both due to the influence they have on ecosystem composition and increased pressure on high-alpine species as well as the implications they have on carbon storage potential. Warming is occurring at a more rapid rate at higher elevation and latitude, meaning we are likely to continue seeing forest expansions occurring in these areas. However, these trends have not been uniform, with more than $30 \%$ of treelines remaining stationary or even declining. While treelines may be overall temperature-limited advancement of trees is only possible when seedlings are capable of establishing and surviving at higher elevation or latitude than the current treeline. These sites offer less protection, and other factors such as strong winds, frost injuries or physical damage from snow cover may significantly reduce the chance of seedling survival. In addition, as temperatures are warming trees located in dryer areas may face more frequent and intense water stress. Hence, a warmer climate may not be positive for all treelines. Treeline movement is likely to alter the ecosystem carbon storage capacity, although the exact impact this will have is yet to be established. Treelines migrating into high alpine ecosystems with thin soils and little vegetation may increase the overall storage capacity while treelines migrating into carbon rich tundra may significantly reduce the soil carbon storage. Hence, the impact is likely to vary depending on the local ecosystem. One of the main questions that remain is if the forest expansion occurring across the alpine landscapes is capable of absorbing and storing sufficient amounts of carbon to offset the potentially significant loss of carbon dioxide expected to occur from the loss of arctic tundra landscapes.

Open Access This article is distributed under the terms of the Creative Commons Attribution 4.0 International License (http://creativecommons. org/licenses/by/4.0/), which permits unrestricted use, distribution, and reproduction in any medium, provided you give appropriate credit to the original author(s) and the source, provide a link to the Creative Commons license, and indicate if changes were made. 


\section{References}

Alftine K, Malanson G, Fagre D (2003) Feedback-Driven Response to Multidecadal Climatic Variability at an Alpine Treeline. Phys Geogr 24(6): 520-535. https://doi.org/10.2747/0272-3646.24.6.520

Ameztegui A, Coll L, Brotons L, et al. (2016) Land - use legacies rather than climate change are driving the recent upward shift of the mountain tree line in the Pyrenees. Global Ecol Biogeogr 25(3): 263-273. https://doi.org/10.1111/geb.12407

Andersen M, Baker W (2006) Reconstructing Landscape-scale Tree Invasion Using Survey Notes in the Medicine Bow Mountains, Wyoming, USA. Landscape Ecol 21(2): 243-258. https://doi.org/10.1007/s10980-005-1938-3

Anderson B (2012) Intensification of seasonal extremes given a $2^{\circ} \mathrm{C}$ global warming target. Climate Change 112(2): 325-337. https://doi.org/10.1007/s10584-011-0213-7

$\mathrm{Au}$ TF, Maxwell JT, Novick KA, et al. (2020) Demographic shifts in eastern US forests increase the impact of late - season drought on forest growth. Ecography 43(10): 1475-1486. https://doi.org/10.1111/ecog.05055

Aune S, Hofgaard A, Soderstrom L (2011) Contrasting climateand land-use-driven tree encroachment patterns of subarctic tundra in northern Norway and the Kola Peninsula. Can J For Res 41(3): 437-449. https://doi.org/10.1139/X10-086

Autio J, (2006). Environmental factors controlling the position of the actual timberline and treeline of the fells of Finish Scandinavia. Dissertation, University of Oulu, Oulu, Finland

Bader M, van Geloof I, Rietkerk M (2007) High solar radiation hinders tree regeneration above the alpine treeline in northern Ecuador. Plant Ecol 191(1): 33-45. https://doi.org/10.1007/s11258-006-9212-6

Baker BB (2007) Advancing Treeline and Retreating Glaciers: Implications for Conservation in Yunnan, P.R. China. Arct Antarct Alp Res 39(2): 200-209.

Bergeron O, Margolis HA, Black TA, et al. (2007) Comparison of carbon dioxide fluxes over three boreal black spruce forests in Canada. Glob Change Biol 13: 89-107.

https: //doi: 10.1111/j.1365-2486.2006.01281.x

Bhatt US, Walker D, Raynolds M, et al. (2010) Circumpolar Arctic Tundra Vegetation Change Is Linked to Sea Ice Decline. Earth Interact 14(8): 1. https://doi.org/10.1175/2010EI315.1

Blinova I, Chmielewski F-M (2015) Climatic warming above the Arctic Circle: are there trends in timing and length of the thermal growing season in Murmansk Region (Russia) between 1951 and 2012? Int J Biometeorol 59(6): 693-705. https://doi.org/10.1007/s00484-014-0880-y

Bonnaventure PP, Lewkowicz AG (2012) Permafrost probability modeling above and below treeline, Yukon, Canada. Cold Regi Sci Technol 79-80: 92-106. https://doi.org/10.1016/j.coldregions.2012.03.004

Bunn A, Goetz S, Kimball J, et al. (2007) Northern high latitude ecosystems respond to climate change. Eos 88(34): 333-335. https://doi.org/10.1029/2007EO340001

Butler D, Dechano L (2001) Environmental change in Glacier National Park, Montana: an assessment through repeat photography from fire lookout. Phys Geogr 22(4): 291-304. https://doi.org/10.1080/02723646.2001.10642744

Cahoon SMP, Sullivan PF, Shaver GR, et al. (2012) Interactions among shrub cover and the soil microclimate may determine future Arctic carbon budgets. Ecol Lett 15(12): 1415-1422. https://doi.org/10.1111/j.1461-0248.2012.01865.x

Camarero J, Gutiérrez E (2004) Pace and Pattern of Recent Treeline Dynamics: Response of Ecotones to Climatic Variability in the Spanish Pyrenees. Climatic Change 63(1): 181200. https://doi.org/10.1023/B:CLIM.o0o0018507.71343.46

Carrara PE, McGeehin JP (2015) Evidence of a higher lateHolocene treeline along the Continental Divide in central Colorado. The Holocene 25(11): 1829-1837. https://doi.org/10.1177/0959683615591353

Catalan J, Pla S, Rieradevall M, et al. (2002) Lake Redó ecosystem response to an increasing warming the Pyrenees during the twentieth century. J Paleolimnol 28(1): 129-145. https://doi.org/10.1023/A:1020380104031

Celis G, Mauritz M, Bracho R, et al. (2017) Tundra is a consistent source of $\mathrm{CO} 2$ at a site with progressive permafrost thaw during 6 years of chamber and eddy covariance measurements. J Geophys Res: Biogeo 122(6): 1471-1485. https://doi.org/10.1002/2016JGo03671

Christensen TR, Michelsen A, Jonasson S, et al. (1997) Carbon Dioxide and Methane Exchange of a Subarctic Heath in Response to Climate Change Related Environmental Manipulations. Oikos 79(1): 34-44. https://doi.org/10.2307/3546087

Cieraad E, McGlone MS, Huntley B (2014) Southern Hemisphere temperate tree lines are not climatically depressed. J Biogeogr 41(8): 1456-1466. https://doi.org/10.1111/jbi.12308

Compostella C, Caccianiga M (2017) A comparison between different treeline types shows contrasting responses to climate fluctuations. Plant Biosyst 151(3): 436-449.

https://doi.org/10.1080/11263504.2016.1179695

Coop JD, Givnish TJ (2007) Spatial and temporal patterns of recent forest encroachment in montane grasslands of the Valles Caldera, New Mexico, USA. J Biogeogr 34(5): 914-927. https://doi.org/10.1111/j.1365-2699.2006.01660.x

Coops NC, Morsdorf F, Schaepman ME, et al. (2013) Characterization of an alpine tree line using airborne LiDAR data and physiological modeling. Glob Change Biol 19(12): 3808-3821. https://doi.org/10.1111/gcb.12319

Danby RK, Hik DS (2007) Variability, contingency and rapid change in recent subarctic alpine tree line dynamics. J Ecol 95(2): 352-363. https://doi.org/10.1111/j.1365-2745.2006.01200.x

Dawes MA, Philipson CD, Fonti P, et al. (2015) Soil warming and $\mathrm{CO} 2$ enrichment induce biomass shifts in alpine tree line vegetation. Glob Change Biol 21(5): 2005-2021. https://doi.org/10.1111/gcb.12819

DeMarco J, Mack MC, Bret - Harte MS, et al. (2014) Long term experimental warming and nutrient additions increase productivity in tall deciduous shrub tundra. Ecosphere 5(6): 1-22. https://doi.org/10.1890/ES13-00281.1

Dinca L, Nita MD, Hofgaard A, et al. (2017) Forests dynamics in the montane-alpine boundary: a comparative study using satellite imagery and climate data. Clim Res 73: 79-110 https://doi.org/ 10.3354/cro1452

Dirnbock T, Essl F, Rabitsch W (2011) Disproportional risk for habitat loss of high-altitude endemic species under climate change.(Report). Glob Change Biol 17(2): 990. https://doi.org/10.1111/j.1365-2486.2010.02266.x

Dirnböck T, Essl F, Rabitsch W (2011) Disproportional risk for habitat loss of high - altitude endemic species under climate change. Glob Change Biol 17(2): 990-996.

https://doi.org/10.1111/j.1365-2486.2010.02266.x

Djukic I, Zehetner F, Tatzber M, et al. (2010) Soil organic matter stocks and characteristics along an Alpine elevation gradient. J Plant Nutr Soil Sc 173(1): 30-38. https://doi.org/10.1002/jpln.200900027

Dullinger S, Dirnböck T, Grabherr G (2004) Modelling climate change - driven treeline shifts: relative effects of temperature increase, dispersal and invasibility. J Ecol 92(2): 241-252. https://doi.org/10.1111/j.0022-0477.2004.00872.X

Epstein HE, Raynolds MK, Walker DA, et al. (2012) Dynamics of aboveground phytomass of the circumpolar arctic tundra during the past three decades. Environ Res Lett 7(1): 015506. https://doi.org/10.1088/1748-9326/7/1/015506

Esper J, Schweingruber F (2004) Large-scale treeline changes recorded in Siberia. Geophys Res Lett 31(6). https://doi.org/10.1029/2003GL019178

Euskirchen ES, Bret - Harte MS, Scott GJ, et al. (2012) Seasonal patterns of carbon dioxide and water fluxes in three representative tundra ecosystems in northern Alaska. Ecosphere 3(1): 1-19. https://doi.org/10.1890/ES11-00202.1

Fernandez CW, Kennedy PG, (2016). Revisiting the 'Gadgil effect': do interguild fungal interactions control carbon cycling in forest soils? New Phytol 209(4): 1382-1394. https://doi.org/ 10.1111/nph.13648

Feurdean A, Gałka M, Tanţău I, et al. (2016) Tree and timberline shifts in the northern Romanian Carpathians 
during the Holocene and the responses to environmental changes. Quaternary Sci Rev 134: 100-113.

https://doi.org/10.1016/j.quascirev.2015.12.020

Field CB, Lobell DB, Peters HA, et al. (2007) Feedbacks of Terrestrial Ecosystems to Climate Change. Annu Rev Env Resour 32: 1-29.

https://doi.org/10.1146/annurev.energy.32.053006.141119

Gehrig-Fasel J, (2007). Treeline and climate change: analyzing and modeling patterns and shifts in the Swiss Alps, PhD thesis, Université de Lausanne, Lausanne

Gehrig - Fasel J, Guisan A, Zimmermann NE (2007) Tree line shifts in the Swiss Alps: Climate change or land abandonment? J Veg Sci 18(4): 571-582.

https://doi.org/10.1111/j.1654-1103.2007.tbo2571.x

Grace J, Berninger F, Nagy L (2002) Impacts of Climate Change on the Tree Line. Ann Bot-London 90(4): 537-544. https://doi.org/10.1093/aob/mcf222

Groendahl L, Friborg T, Soegaard H (2007) Temperature and snow-melt controls on interannual variability in carbon exchange in the high Arctic. Theor Appl Climatol 88(1): 111125. https://doi.org/10.1007/s00704-005-0228-y

Grogan P, Chapin III F (1999) Arctic soil respiration: effects of climate and vegetation depend on season. Ecosystems 2(5): 451-459.

Harsch MA, Buxton R, Duncan RP, et al. (2012) Causes of tree line stability: stem growth, recruitment and mortality rates over 15 years at New Zealand Nothofagus tree lines. J Biogeogr 39(11): 2061-2071.

https://doi.org/10.1111/j.1365-2699.2012.02763.x

Harsch MA, Hulme PE, McGlone MS, et al. (2009) Are treelines advancing? A global meta - analysis of treeline response to climate warming. Ecol Lett 12(10): 1040-1049.

https://doi.org/10.1111/j.1461-0248.2009.01355.x

Hartley IP, Garnett MH, Sommerkorn M, et al. (2012) A potential loss of carbon associated with greater plant growth in the European Arctic. Nat Clim Change 2(12): 875 https://doi.org/10.1038/nclimate1575

Hobbie SE, Chapin FS, III (1998) The response of tundra plant biomass, above-ground production, nitrogen, and $\mathrm{CO}$ flux to experimental warming. Ecology 79(5): 1526-1544. https://doi.org/10.2307/176774

Hofgaard A, Tømmervik H, Rees G, et al. (2013) Latitudinal forest advance in northernmost Norway since the early 20th century. J Biogeogr 40(5): 938-949. https://doi.org/10.1111/jbi.12053

Holtmeier F-K, Broll G (2010) Wind as an Ecological Agent at Treelines in North America, the Alps, and the European Subarctic. Phys Geogr 31(3): 203-233.

https://doi.org/10.2747/0272-3646.31.3.203

Holtmeier FK, Broll G (2007) Treeline advance - driving processes and adverse factors. Landscape Online 1(1): 1-33. https://doi.org/10.3097/LO.200701

Holtmeier FK, Broll G (2011) Response of Scots Pine (Pinus sylvestris) to Warming Climate at Its Altitudinal Limit in Northernmost Subarctic Finland. Arctic 64(3): 269-280.

Holtmeier FK, Broll G (2012) Landform Influences on Treeline Patchiness and Dynamics in a Changing Climate. Phys Geogr 33(5): 403-437. https://doi.org/10.2747/0272-3646.33.5.403

Iain PH, Mark HG, Martin S, et al. (2012) A potential loss of carbon associated with greater plant growth in the European Arctic. Nat Clim Change 2(12): 875.

https://doi.org/10.1038/nclimate1575

IPCC, (2014). Synthesis Report. Contribution of Working Groups I, II and III to the Fifth Assessment Report of the Intergovernmental Panel on Climate Change. Climate Change 2014. Core Writing Team, R. K. Pachauri and L. A. Meyer. Geneva, Switzerland, IPCC.

Jake MA, Jeffrey MD, Jonathan ML (2015) Novel competitors shape species' responses to climate change. Nature 525(7570): 515. https://doi.org/10.1038/nature14952

Jørgensen SE, (2009). Ecosystem ecology. Editor-in-chief, Sven Erik Jørgensen. Amsterdam, Netherlands; Boston, Mass., Elsevier.

Kaplan JO, New M (2006) Arctic climate change with a $2 \mathrm{C}$ global warming: Timing, climate patterns and vegetation change. Climatic Change 79(3-4): 213-241.

https://doi.org/10.1007/s10584-006-9113-7
Kauppi P, Posch M, Pirinen P (2014) Large Impacts of Climatic Warming on Growth of Boreal Forests since 1960. PLoS ONE 9(11). https://doi.org/10.1371/journal.pone.0111340

Kelsey KC, Leffler AJ, Beard KH, et al. (2016) Interactions among vegetation, climate, and herbivory control greenhouse gas fluxes in a subarctic coastal wetland. Journal Geophys Res: Biogeosci 121(12): 2960-2975.

https://doi.org/10.1002/2016JGoo3546

Kharuk VI, Ranson KJ, Im ST, et al. (2009) Response of Pinus sibirica and Larix sibirica to climate change in southern Siberian alpine forest-tundra ecotone. Scand J Forest Res 24(2): 130-139.https://doi.org/10.1080/02827580902845823

Körner C (1998) A re-assessment of high elevation treeline positions and their explanation. Oecologia 115(4): 445-459. https://doi.org/10.1007/s004420050540

Körner C, Paulsen J (2004) A world-wide study of high altitude treeline temperatures. J Biogeogr 31(5): 713-732.

Körner C, Riedl S, (2012). Alpine Treelines Functional Ecology of the Global High Elevation Tree Limits, Basel : Springer.

Kruse S, Wieczorek M, Jeltsch F, et al. (2016) Treeline dynamics in Siberia under changing climates as inferred from an individual-based model for Larix. Ecol Model 338: 101-121. https://doi.org/10.1016/j.ecolmodel.2016.08.003

Kullman L (2005) Wind-conditioned 2oth century decline of birch treeline vegetation in the Swedish Scandes. Arctic 58(3): 286. https://doi.org/10.14430/arctic430

Kullman L (2007) Tree line population monitoring of Pinus sylvestris in the Swedish Scandes, 1973-2005: implications for tree line theory and climate change ecology. J Ecol 95(1): 41-52. https://doi.org/10.1111/j.1365-2745.2006.01190.x

Linderholm HW (2006) Growing season changes in the last century. Forest Meteorol 137(1): 1-14. https://doi.org/10.1016/j.agrformet.2006.03.006

Lloyd A, Fastie C (2002) Spatial and Temporal Variability in the Growth and Climate Response of Treeline Trees in Alaska. Climatic Change 52(4): 481-509. https://doi.org/10.1023/A:1014278819094

Lloyd AH (2005) Ecological histories from Alaskan tree lines provide insight into future change. Ecology 86(7): 1687-1695.

Lloyd AH, Graumlich LJ (1997) Holocene dynamics of treeline forests in the Sierra Nevada. Ecology 78(4): 1199-1210. https://doi.org/10.1890/00129658(1997)078[1199:HDOTFI]2.0.CO2

Lund M, Falk JM, Friborg T, et al. (2012) Trends in CO 2 exchange in a high Arctic tundra heath, 2000-2010. J Geophys Res Biogeo $117(\mathrm{G} 2)$ https://doi.org/10.1029/2011JGo01901

Mamet SD, Kershaw GP (2012) Subarctic and alpine tree line dynamics during the last 400 years in north - western and central Canada. J Biogeogr 39(5): 855-868. https://doi.org/10.1111/j.1365-2699.2011.02642.x

McGlone MS, Wilmshurst JM, Richardson SJ, et al. (2019) Temperature, Wind, Cloud, and the Postglacial Tree Line History of Sub-Antarctic Campbell Island. Forests 10(11): 998. https://doi.org/10.3390/f10110998

Moen J, Aune K, Edenius L, et al. (2004) Potential Effects of Climate Change on Treeline Position in the Swedish Mountains. Ecol Soc 9(1). https://doi.org/10.5751/ES-00634-090116

Natali SM, Schuur EAG, Mauritz M, et al. (2015) Permafrost thaw and soil moisture driving $\mathrm{CO}_{2}$ and $\mathrm{CH}_{4}$ release from upland tundra. J Geophys Res Biogeo 120(3): 525-537. https://doi.org/10.1002/2014JGo02872

Nicklen EF, Roland CA, Ruess RW, et al. (2016) Local site conditions drive climate-growth responses of Picea mariana and Picea glauca in interior Alaska. Ecosphere 7(10). https://doi.org/10.1002/ecs2.1507

Nogués-Bravo D, Araújo MB, Errea MP, et al. (2007) Exposure of global mountain systems to climate warming during the 21st Century. Global Environ Chang 17(3): 420-428. https://doi.org/10.1016/j.gloenvcha.2006.11.007

Oberbauer SF, Elmendorf SC, Troxler TG, et al. (2013) Phenological response of tundra plants to background climate variation tested using the International Tundra Experiment. Phil Trans R Soc B 368(20120481).

https://doi.org/10.1098/rstb.2012.0481

Öberg L, Kullman L (2012) Contrasting short-term performance 
of mountain birch (Betula pubescens ssp. czerepanovii) treeline along a latitudinal continentality-maritimity gradient in the southern Swedish Scandes. Fennia - Int J Geogr 190(1): 19.

Öberg L, Kullman L (2012) Contrasting short-term performance of mountain birch (Betula pubescens ssp. czerepanovii) treeline along a latitudinal continentality-maritimity gradient in the southern Swedish Scandes. Fennia-Int J Geogr 19O(1): 19-40.

Parker TC, Subke JA, Wookey PA (2015) Rapid carbon turnover beneath shrub and tree vegetation is associated with low soil carbon stocks at a subarctic treeline. Glob Change Biol 21(5): 2070-2081. https://doi.org/10.1111/gcb.12793

Paulsen J, Körner C (2014) A climate-based model to predict potential treeline position around the globe. Alpine Bot 124(1): 1-12. https://doi.org/10.1007/s00035-014-0124-0

Paulsen J, Weber UM (2000) Tree Growth near Treeline: Abrupt or Gradual Reduction with Altitude? Arctic, Antarctic, and Alpine Research 32(1): 14-20.

https://doi.org/10.2307/1552405

Pearson RG, Phillips SJ, Loranty MM, et al. (2013) Shifts in Arctic vegetation and associated feedbacks under climate change. Nat Clim Change 3(7): 673 .

https://doi.org/10.1038/nclimate1858

Pecl GT, Araújo MB, Bell JD, et al. (2017) Biodiversity redistribution under climate change: Impacts on ecosystems and human well-being. Science 35(6332): 1 .

https://doi.org/ 10.1126/science.aaig214

Qian H, Joseph R, Zeng N (2010) Enhanced terrestrial carbon uptake in the Northern High Latitudes in the 21st century from the Coupled Carbon Cycle Climate Model Intercomparison Project model projections. Glob Change Biol 16(2): 641-656. https://doi.org/10.1111/j.1365-2486.2009.01989.x

Salmon VG, Soucy P, Mauritz M, et al. (2016) Nitrogen availability increases in a tundra ecosystem during five years of experimental permafrost thaw. Glob Change Biol 22(5): 1927-1941. https://doi.org/10.1111/gcb.13204

Salzer MW, Bunn AG, Graham NE, et al. (2013) Five millennia of paleotemperature from tree-rings in the Great Basin, USA. Clim Dynam 42(5-6): 1517-1526.

https://doi.org/10.1007/s00382-013-1911-9

Schmid S, Zierl B, Bugmann H (2006) Analyzing the carbon dynamics of central European forests: comparison of BiomeBGC simulations with measurements. Reg Environ Change 6(4): 167-18o. https://doi.org/10.1007/s10113-006-0017-x

Shiyatov S, Terent'ev M, Fomin V (2005) Spatiotemporal dynamics of forest-tundra communities in the polar urals. Russ J Ecol+ 36(2): 69-75.

https://doi.org/10.1007/s11184-005-0051-9

Sitch S, McGuire AD, Kimball J, et al. (2007) Assessing the Carbon Balance of Circumpolar Arctic Tundra Using Remote Sensing and Process Modeling. Ecol Appl 17(1): 213-234. https://doi.org/10.189o/10510761(2007)017[0213:ATCBOC]2.0.CO;2

Sørensen MV, Strimbeck R, Nystuen KO, et al. (2017) Draining the Pool? Carbon Storage and Fluxes in Three Alpine Plant Communities. Ecosystems 21: 316-330.

https://doi.org/ 10.1007/s10021-017-0158-4

Sturm M, Racine C, Tape K (2001) Increasing shrub abundance in the Arctic. Nature 411(6837): 546-547.

Svenning JC, Sandel B (2013) Disequilibrium vegetation dynamics under future climate change. Am J Bot 100(7): 1266-1286. https://doi.org/10.3732/ajb.1200469

Tingstad L, Olsen S, Klanderud K, et al. (2015) Temperature, precipitation and biotic interactions as determinants of tree seedling recruitment across the tree line ecotone. Oecologia 179(2):599-608.https://doi.org/10.1007/s00442-015-3360-0

Treml V, Chuman T (2015) Ecotonal Dynamics of the Altitudinal Forest Limit are Affected by Terrain and Vegetation Structure Variables: An Example from the Sudetes Mountains in Central Europe. Arct Antarct Alp Res 47(1): 133-146. https://doi.org/10.1657/AAARo013-108

Van Bogaert R, Haneca K, Hoogesteger J, et al. (2011) A century of tree line changes in sub-Arctic Sweden shows local and regional variability and only a minor influence of 2oth century climate warming.(Report). J Biogeogr 38(5): 907 https://doi.org/10.1111/j.1365-2699.2010.02453.x

Vittoz P, Rulence B, Largey T, et al. (2008) Effects of Climate and Land-Use Change on the Establishment and Growth of Cembran Pine (Pinus cembra L.) over the Altitudinal Treeline Ecotone in the Central Swiss Alps. Arct Antarct Alp Res 40(1): 225-232. https://doi.org/10.1657/1523-0430(06-010)[VITTO $\mathrm{Z}] 2.0 . \mathrm{CO} ; 2$

Walker MD, Wahren $\mathrm{CH}$, Hollister RD, et al. (2006) Plant community responses to experimental warming across the tundra biome. P Natl Acad Sci USA 103(5): 1342. https://doi.org/10.1073/pnas.0503198103

Wallentin G, Tappeiner U, Strobl J, et al. (2008) Understanding alpine tree line dynamics: An individual-based model. Ecol Model 218(3-4): 235-246. https://doi.org/10.1016/j.ecolmodel.2008.07.005

Wania R, Ross I, Prentice IC (2009) Integrating peatlands and permafrost into a dynamic global vegetation model: 1 Evaluation and sensitivity of physical land surface processes. Glob Biogeochem Cy 23(3) https://doi.org/10.1029/2008GBoo3412

Ward A, (2016). The extent and value of carbon stored in mountain grasslands and shrublands globally, and the prospects for using climate finance to address natural resource management issues. $\mathrm{PhD}$ Thesis, University ofQueensland. https://doi.org/10.14264/uql.2016.571

Warszawski L, Friend A, Ostberg S, et al. (2013) A multi-model analysis of risk of ecosystem shifts under climate change. Environ Res Lett 8(4): 1-10.

https://doi.org/10.1088/1748-9326/8/4/044018

Weih M, Karlsson PS (2002) Low Winter Soil Temperature Affects Summertime Nutrient Uptake Capacity and Growth Rate of Mountain Birch Seedlings in the Subarctic, Swedisn Lapland. Arct Antarct Alp Res 34(4): 434-439. 1 https://doi.org/o.1080/15230430.2002.12003514

Wilmking M, Harden J, Tape K (2006) Effect of tree line advance on carbon storage in NW Alaska. J Geophys Res: Biogeo 111(G2). https://doi.org/10.1029/2005JGo00074

Wilmking M, Juday GP (2005) Longitudinal variation of radial growth at Alaska's northern treeline-recent changes and possible scenarios for the 21st century. Global Planet Change 47(2): 282-300.https://doi.org/10.1016/j.gloplacha.2004.10.017

Wilmking M, Juday GP, Barber VA, et al. (2004) Recent climate warming forces contrasting growth responses of white spruce at treeline in Alaska through temperature thresholds. Glob Change Biol 10(10): 1724-1736.

https://doi.org/10.1111/j.1365-2486.2004.00826.x

Wilmking M, Sanders T, Zhang Y, et al. (2012) Effects of Climate, Site Conditions, and Seed Quality on Recent Treeline Dynamics in NW Russia: Permafrost and Lack of Reproductive Success Hamper Treeline Advance? Ecosystems 15(7): 1053-1064. https://doi.org/10.1007/s10021-012-9565-8

Wipf S, Stoeckli V, Bebi P (2009) Winter climate change in alpine tundra: plant responses to changes in snow depth and snowmelt timing. Climatic Change 94(1): 105-121.

https://doi.org/10.1007/s10584-009-9546-x

Woodward C, Shulmeister J, Larsen J, et al. (2014) The hydrological legacy of deforestation on global wetlands. Science 346(6211): 844-847.

https://doi.org/10.1126/science.1260510

Zhang W, Liu P, Feng Q, et al. (2018) The spatiotemporal responses of Populus euphratica to global warming in Chinese oases between 1960 and 2015. J Geogr Sci 28(5): 579-594. https://doi.org/10.1007/s11442-018-1492-y

Zhang W, Miller P, Smith B, et al. (2013) Tundra shrubification and tree-line advance amplify arctic climate warming : results from an individual-based dynamic vegetation model. Environ Res Lett 8(3). https://doi.org/10.1088/1748-9326/8/3/034023

Ziegler SE, Benner R, Billings SA, et al. (2017) Climate Warming Can Accelerate Carbon Fluxes without Changing Soil Carbon Stocks. Front in Earth Sci 5 .

https://doi.org/10.3389/feart.2017.00002 